\title{
PUBLIC CONTRACTS AND FAIR TRADE
}

\author{
[Veřejné zakázky a fair trade] \\ Martina Hrůzová ${ }^{1}$ \\ ${ }^{1}$ Slezská univerzita, Obchodně podnikatelská fakulta, Univerzitní nám. 1934/3,733 40 Karviná \\ Email:hruzova.martina@centrum.cz
}

\begin{abstract}
This article analyzes the opportunities to include the principles of fair trade to announce public procurement. To announce public procurement can be also incorporated social (socially responsible) criteria. The first part of the paper is devoted to the characteristics and principles of fair trade and the second part is devoted to the analysis of socially responsible procurement and practical demonstration of how to add the Fair Trade criteria into public procurement.
\end{abstract}

Keywords: fair trade, public contracts, public sector, social responsibility.

JEL classification: H57, H59

Doručeno redakci: 10.10.2013; Recenzováno: 5.5.2014; 10.5.2014; Schváleno k publikování: 27.5.2015

\section{Úvod}

Oblast veřejných zakázek je stále aktuální s neustále se měnící. Je to logické, jedná se o přerozdělování peněz. Př́íspěvek se zaměřuje na to, jakým způsobem je možné zahrnout principy fair trade právě do veřejných zakázek. Jedná se o to, aby veřejné finanční prostředky, byly vynakládány nejen hospodárně, efektivně a účelně, ale také společensky odpovědně. Je potřebné, aby veřejní zadavatelé, tam kde je to vhodné správným způsobem zapracovali fair trade principy do vypisovaných veřejných zakázek.

První část př́íspěvku je orientována na pojetí, vznik, současnost a principy fungování fair trade v ČR a ve světě. V druhé části příspěvku je vymezeno společensky odpovědné zadávání veřejných zakázek a následně praktická ukázka možností jak fair trade principy vpravit do systému veřejných zakázek. Na závěr je uveden průzkum, který se zabývá aplikací principů fair trade ve veřejných zakázkách u vybraných zadavatelů veřejných zakázek. Cílem př́spěvku je tedy analýza eventualit jak do oblasti veřejných zakázek aplikovat společenskou odpovědnost prostřednictvím fair trade principů.

\section{Pojetí, vznik a současnost fair trade}

Organizace Fairtrade Česko a Slovensko definuje fair trade, neboli spravedlivý obchod, jako obchod, který dává možnost pěstitelům, řemeslníkům a zaměstnancům v zemích Afriky, Asie a Latinské Ameriky, důstojně se uživit svou prací. K tomu je nutná spolupráce jak na straně výrobců, tak na straně spotřebitelů. Pro výrobce fair trade nabízí spravedlivé obchodní podmínky, důstojný život s možností plánování své budoucnosti. Spotřebitelé mohou prostřednictvím fair trade přispět k omezení těchto negativních vlivů - snižování chudoby ve světě, vykořist'ování, potírání dětské práce a ničení životního prostředí.

Vznik fair trade lze datovat po roce 1945, tedy do poválečného období. Tehdy se církevní organizace v USA (jako první v USA to byla církevní organizace „Ten Thousand Villages“) a Evropě (britská církevní organizace Oxfam UK) rozhodly dovážet řemeslné výrobky $\mathrm{z}$ tehdejších kolonií v Africe, Asii i Latinské Americe. ${ }^{1}$

\footnotetext{
${ }^{1}$ Více na http://www.fairtrade-cesko.cz/
} 
V současnosti je ve světě na 2,5 milionu fairtradových řemeslníků a pěstitelů. V roce 2012 dostali certifikovaní pěstitelé na sociální prémii 80 milionů Eur. V roce 2012 fairtrade maloobchodní tržby na celém světě dosáhly téměř 5 miliard Eur.

Podle výše obratu patří mezi TOP fairtradové produkty káva, banány, cukr, kakao, čaj, bavlna, atd. ${ }^{2}$ Tyto údaje dokládají rostoucí význam hnutí fair trade ve světě.

\section{Organizace, systémy a kampaně}

Fair trade má zřejmý mezinárodní rozměr. Podstatné jsou proto zastř̌šující organizace, které umožňují komunikaci mezi organizacemi fair trade i prezentaci fair trade navenek. Jsou to:

WFTO (World Fair Trade Organization) - do jara 2009 IFAT (International Fair Trade Association - vznikla v roce 1989) - sdružení výrobců, dovozců i prodejců, spojující všechny články řetězce Fair trade z celého světa. Poskytuje svým členům známku, která potvrzuje, že se jedná o skutečné organizace fair trade. WFTO má asi 300 členů ze 70 zemí.

FLO (Fairtrade Labelling Organizations International) - vznikla v roce 1997 a je to sdružení 19 národních iniciativ z 24 zemí. Od roku 2002 spustila systém standardů pro certifikaci výrobků ochrannou známkou FAIRTRADE ${ }^{\circledR}$ a spravuje registr certifikovaných výrobců. Fairtrade International sídlí v Bonnu a jejím hlavním úkolem je tedy tvorba a úprava standardů certifikace Fairtrade, udávání minimálních výkupních cen, propagace známky Fairtrade a její opatrování a také kampaně na podporu spravedlivého obchodování. Polovinu voleného vedení organizace tvoří zástupci pěstitelských družstev. ${ }^{3}$

EFTA (European Fair Trade Association) - založená v roce 1990, je to sdružení 11 největších evropských dovozců fair trade (německá Gepa, italské CTM Altromercato, britský Traidcraft, švýcarské Claro, nizozemská Fair Trade Organisatie, belgičtí Oxfam Wereldwinkels a Magasins du Monde Oxfam, francouzský SolidarMonde, rakouská EZA, španělští IDEAS a Intermon Oxfam). ${ }^{4}$

Existují dva systémy fairtrade:

Systém certifikace FAIRTRADE ${ }^{\circledR}$ - certifikační známka FAIRTRADE ${ }^{\circledR}$ může být použita na obalu výrobku v př́ípadě, že pěstitel, dovozce i zpracovatel pravidelně prochází nezávislou kontrolou ověřující shodu (certifikační proces) se standardy Fairtrade International. Jedná se o nezávislé označení, které spotřebitelům zaručuje, že výrobky splňují stanovené sociální, ekologické a ekonomické požadavky spravedlivého obchodu. Mezi výrobky se schválenými certifikačními standardy patří napřr banány, kakao, káva, sušené ovoce, květiny, čerstvé ovoce a zelenina, ovocné džusy, koření a bylinky, med, ořechy a oleje, quinoa, rýže, sportovní míče, cukr, bavlna, bambucké máslo, čaj, vinná réva. ${ }^{5}$

Systém založený na členství ve světové fairtradové organizaci World Fair Trade Organization (WFTO) - tato organizace sdružuje pěstitele a obchodníky, kteří se věnují stoprocentně pouze férovému obchodování. Mezi takovéto organizace patř́i například Gepa, EZA, CTM - Altromercato, Oxfam a další. Systém tradičních fairtradových organizací (www.wfto.com) - je založený na členství obchodníků a pěstitelů v organizaci WFTO. Všichni členové se zavazují splňovat základní principy fair trade, systém je založený na důvěře, zboží tedy nemá certifikační známku, ale pouze logo člena WFTO. Ovšem i zde probíhají náhodné kontroly nezávislými auditory. WFTO, respektive její členové, nabízí

\footnotetext{
${ }^{2}$ Více informací ve výročních zprávách Fairtrade international 2005 až 2013 na:http://www.fairtrade.net/annualreports.html

${ }^{3}$ Více na http://www.flo-cert.net/

${ }^{4}$ Více na http://www.european-fair-trade-association.org/efta/

${ }^{5}$ Více na http://www.fairtrade.net/
} 
umělecké, řemeslné a další výrobky např́klad - keramika, sklo, textil, kosmetika, hlavolamy, šperky, hudební nástroje, hračky, doplňky do domácnosti, koberce, fotoalba, kancelářské potřeby, nábytek atd. ${ }^{6}$

\section{Alternativní systémy navazující na fair trade:}

Fair Wear Foundation (FWF) je iniciativa mnoha zainteresovaných stran pracovat na zlepšení podmínek na pracovišti v oděvním a textilním průmyslu. Řídí ji odbory, nevládní organizace a podnikatelská sdružení. FWF ověří, že jeho členové dodržují FWF kodex práce praxe $\mathrm{v}$ jejich dodavatelských řetězcích. FWF byla založena $\mathrm{v}$ roce 1999 , v roce 2010 má více než padesát členů z celé Evropy a je aktivní v mnoha zemích, jako je Čína, Indie, Bangladéš, Turecko atd. ${ }^{7}$

Werkgroep Duurzame Natuursteen (WGDN) sjednocuje různé iniciativy, dovozce a odborné nevládní organizace $\mathrm{k}$ síti pro udržitelný přírodní kámen. Pracovní skupina byla založena v roce 2007 v Nizozemí a spolupracuje na vytváření společných standardů a postupů důležitých ke vzniku důvěryhodné a jednotné známky. ${ }^{8}$

Forest Stewardship Council (FSC) - mezinárodní nevládní nezisková organizace se sídlem v Bonnu prosazuje šetrné lesní hospodaření pomocí důvěryhodného certifikačního systému. Byl založen v roce 1993 více než 500 subjekty z řad lesníků, zpracovatelů, ekologických a sociálních nevládních organizací a certifikačních firem. ${ }^{9}$

Flower Label Program (FLP) - certifikace eticky obchodovaných květin. V Německu lze FLP květiny najít u více než 1000 prodejců květin a jsou stejně drahé jako necertifikované. ${ }^{10}$

Pro úspěšné fungování, propagaci a podporu fair trade jsou důležité kampaně a projekty. Například kampaň Fairtraidová města (součástí kampaně jsou také školy a církve) kampaň Fairtradových měst (Fairtrade towns) odstartovala v roce $2001 \mathrm{v}$ britském městě Garstang z iniciativy Bruce Crowthera. Dnes je tato kampaň rožšřřená doslova po celém světě (přes 1400 měst z 23 zemí světa) a přidávají se další a další města. ${ }^{11}$

Kampaň Fairtradová města jako mezinárodní iniciativou označování míst, kde je podporován fair trade. Cílem kampaně je osvěta fair trade a podpora prodeje fairtradových produktů v daném městě. Pro města představuje status nástroj naplňování národních i mezinárodních politických cílů v oblasti udržitelného rozvoje a zároveň marketingový nástroj, díky kterému ukazují svým občanům a dalším institucím svou společenskou odpovědnost.

Města a jiné veřejné instituce mohou status získat při splnění 5 kritérií:

- vytvoření řídící skupiny za účelem podpory fair trade ve městě,

- město oficiálně podporuje fair trade (podpora fair trade je součástí strategických dokumentů),

- V místních obchodech a kavárnách jsou dostupné fairtradové produkty,

- místní organizace podporují fair trade (školy, nevládní organizace, církve, knihovny apod.),

- místní média informují o fair trade.

Fairtradové školy - status Fairtradová škola mohou získat školy na všech úrovních vzdělávacího systému. Dávají jím najevo svou společenskou odpovědnost a zájem o globální rozvojové vzdělávání.

\footnotetext{
${ }^{6}$ Více na http://www.wfto.com/

${ }^{7}$ Více informací na http://www.fairwear.org/

${ }^{8}$ Více informací na http://duurzaamnatuursteen.nl/en/page/home_en

${ }^{9}$ Více informací na http://www.czechfsc.cz

${ }^{10}$ Více informací na http:// www.fairflowers.de

${ }^{11}$ Aktuální počet Fairtradových měst ve světě je k dispozici na www.fairtradetowns.org
} 
Školy mohou status získat při splnění 5 kritérií:

- vytvoření rídící skupiny za účelem podpory fair trade na škole,

- škola oficiálně podporuje fair trade,

- na škole jsou dostupné fairtradové produkty,

- na škole se vyučují globální rozvojová témata,

- Škola pořádá akce na podporu fair trade a usiluje o medializaci.

Fairtradové církve a náboženské společnosti - využívání fair trade výrobků církvemi a náboženskými společnostmi má zásadní vliv na životy producentů a stav životního prostředí v rozvojových zemích, je účinným nástrojem boje proti chudobě a za zlepšení pracovních podmínek v rozvojovém světě. Jednotlivé sbory se mohou do kampaně zapojit naplněním 5 kritérií:

- minimálně 1 osoba je odpovědná za podporu fair trade,

- sbor oficiálně podporuje fair trade,

- sbor využívá fairtradové produkty pro svou spotřebu,

- o fair trade jsou informování členové sboru,

- sbor pořádá akce na podporu fair trade pro širší veřejnost.

\section{Principy fair trade}

Hnutí fair trade se oficiálně hlásí $k$ deseti obecným principům, které fair trade odlišují od konvenčního mezinárodního obchodu. WFTO definuje principy fair trade:

1. Fair trade vytváří př́ležitost pro ekonomicky znevýhodněné producenty.

2. Transparentnost a odpovědnost.

3. Férové obchodní praktiky.

4. Vyplácení férové ceny.

5. Zajištění žádné dětské a nucené práce.

6. Závazek k nediskriminaci, genderové rovnosti a svobody shromažd’ování.

7. Zajištění dobrých pracovních podmínek.

8. Pozitivní dopad na komunitu.

9. Propagace fair trade.

10. Ochrana životního prostředí.

Horáček $(2012$, s. 17, 18) tyto principy zahrnuje jako dílčí složky do tří hlavních aspektů společenské odpovědnosti a trvalé udržitelnosti rozvoje.

Ekonomický aspekt - lze sem zařadit tyto principy - př́ležitost pro ekonomicky znevýhodněné producenty, férové obchodní praktiky, vyplácení férové ceny a transparentnost a odpovědnost v obchodních vztazích.

Sociální aspekt - tady jsou to - žádná dětská a nucená práce, nediskriminace, genderová rovnost a svoboda shromažd’ování, pozitivní dopad na komunitu.

Ekologický aspekt - ochrana životního prostředí.

Mimo tyto aspekty, avšak neméně důležitá, stojí propagace fair trade, tedy snaha o co největší rozšíř́n í těchto principů fair trade ve společnosti.

\section{Fairtrade v ČR}

V roce 2004 byla v ČR založena Asociace pro fair trade jako platforma pro setkávání neziskových organizací a firem věnujících se obchodování s fairtradovými produkty a jejich propagaci. Členství bylo otevřeno především organizacím aktivně se věnujícím zvyšování obecného povědomí a propagaci fair trade a zabývajícím se dovozem fairtradových produkti̊ na český trh. V roce 2009 se Asociace pro fair trade stala členem FLO jako marketingová organizace pro ČR. V roce 2012 se Asociace pro fair trade přejmenovala na Fairtrade Česká 
republika. V roce 2014 se působení Fairtrade Česká republika rozš́ríilo i na Slovensko. V souvislosti s tím změnila Fairtrade Česká republika svůj název na Fairtrade Česko a Slovensko. ${ }^{12}$

\subsection{Fairtrade Česko a Slovensko}

Fairtrade Česko a Slovensko zastupuje Fairtrade International v České republice a na Slovensku, jde o skupinu právnických osob, která se zabývá marketingovou podporou certifikační známky FAIRTRADE ${ }^{\circledR}$, podporou prodeje fairtradových výrobků a monitoruje český a slovenský trh s fairtradovými produkty. ${ }^{13}$

Řádní členové Fairtrade Česko a Slovensko k 5. 7. 2014:

Arcidiecézní charita Praha - poskytuje řadu sociálních služeb v pražské arcidiecézi a pomoc směřuje i $\mathrm{k}$ těm nejpotřebnějším $\mathrm{v}$ rozvojových zemích. $\mathrm{K}$ jejím činnostem patří i program Adopce na dálku, který Charita založila.

Ekumenická akademie Praha o.s. - je nevládní nezisková organizace, která se zabývá vzděláváním dospělých. Akademie organizuje tematické semináře a konference, připravuje dlouhodobé vzdělávací projekty, vydává publikace, poskytuje konzultace a poradenství, podílí se na kampaních a vytváření sítí apod. Obsahově se zaměřuje na otázky kultury, politiky, vztahů církve a společnosti, sociální spravedlnosti, udržitelného rozvoje a ve významné míře otázkami vztahů Severu a Jihu. Záměrem Akademie je vytvářet fórum pro otevřenou diskusi o těchto otázkách a to $\mathrm{v}$ široké spolupráci s partnerskými institucemi doma i v zahraničí. $\mathrm{V}$ některých př́padech se zabývá i konkrétními projekty (obnova po povodních, produkce krátkého filmu, partnerské obchodování). ${ }^{14}$

Mamacoffee s.r.o. - jedná se o firmu vzniklou z kávových a fair trade nadšenců. Mamacoffee si vytkla cíle přinést na náš trh čerstvě praženou kávu $\mathrm{z}$ celého světa $\mathrm{v}$ té nejvyšší kvalitě a samožrejmě fair trade. V současné době vlastní pražírnu fair trade kávy (první v ČR i celém bývalém východním bloku) a dodávají prvotřídní kávy do řady gastronomických podniků, ale i firem a maloodběratelům. Zároveň připravují zpracování dalších Fairtrade komodit. ${ }^{15}$

NaZemi - nevládní nezisková organizace NaZemi prosazuje globální rozvojové vzdělávání do škol i mimo ně, zasazuje se o zodpovědnost firem v oblasti jejich dodavatelského řetězce a propaguje fair trade jako účinnou podporu chudým pěstitelům a řemeslníkům z rozvojových zemí. Do 1. dubna 2011 existovala pod názvem Společnost pro Fair Trade. Z hlediska zavedení a působení fair trade v ČR je tato organizace nejdůležitějším členem. ${ }^{16}$

Sympatizující členové Fairtrade Česko a Slovensko k 25. 7. 2014:

Miko Káva s.r.o. (www.mikokava.cz), Centrum environmentálnej a etickej výchovy Živica o.s. - nezisková organizace (www.zivica.sk) a Nadácia Integra (www.integra.sk).

\section{Činnosti Fairtrade Česko a Slovensko:}

Vzdělává zpracovatele, obchodníky i laickou veřejnost, administruje licenční řízení s novými obchodními partnery, schvaluje použití známky FAIRTRADE ${ }^{\circledR}$ pro propagační účely sbírá data o fairtradových výrobcích na českém trhu, poskytuje obchodníkům a zpracovatelům informace o možnostech získání certifikace FAIRTRADE ${ }^{\circledR}$, vyjednává s maloobchodníky o zařazení fairtradových produktů do nabídky, informuje, věnuje se osvětové činnosti, zastřšsuje kampaň Fairtradová města, Fairtradové školy a Fairtradové církve a náboženské společnosti, reprezentuje české hnutí fair trade v zahraničí, propojuje a sdružuje obchodníky a organizace činné v oblasti fair trade v ČR a na Slovensku.

\footnotetext{
${ }^{12}$ Více informací na http://www.fairtrade-cesko.cz/\#!o-nas/nasehistorie

${ }^{13}$ Více informací na http://www.fairtrade-cesko.cz/

${ }^{14}$ Více informací na http://www.ekumakad.cz/

${ }^{15}$ Více informací na http://www.mamacoffee.cz/

${ }^{16}$ Více informací na http://www.nazemi.cz/
} 


\subsection{Kampaně fair trade $v$ ČR}

V lednu 2011 se k celosvětové kampani Fairtradová města (školy a církve) přidala i Česká republika. Iniciativu u nás koordinují Fairtrade Česko a Slovensko, NaZemi a Ekumenická akademie Praha. Prvními Fairtradovými městy se u nás stala 14. záŕí 2011 současně města Litoměřice a Vsetín. K 1. 7. 2014 jsou Fairtradovými městy také Český Krumlov, Hodonín, Mladá Boleslav, Třebíč a Volyně. Žadatelé jsou Brno, Kroměříž a Tišnov. ${ }^{17}$

Prvními dvěma Fairtradovými školami v České republice se staly Masarykova ZŠ, Litoměřice a SŠ a JŠ Volyně. K 1. 7. 2014 jsou Fairtradovými školami také Ekonomická fakulta Jihočeské univerzity v Českých Budějovicích, Fakulta tropického zemědělství na České zemědělské univerzitě v Praze, Hotelová škola Třebíč, ZŠ Pod Skalkou v Rožnově pod Radhoštěm, ZŠ Rokytnice, Vsetín a ZŠ Svážná v Mostě. Deset dalších škol o tento status žádá. ${ }^{18}$

K 1. 7. 2014 je v ČR také 7 Fairtradových církví a náboženských společností a 5 jich o tento status žádá. ${ }^{19}$

\subsection{Prodej fairtradových produktů}

V první tabulce je uveden vývoj prodeje fairtradových produktů v ČR od roku 2005 do roku 2012. V roce 2010 byl nárůst spotřeby zapř́činěn vstupem maloobchodních řetězců na trh s fairtradovými produkty. Jak je z tabulky patrné, v roce 2012 se zvýšil prodej fairtradových produktů o $23 \%$ oproti roku 2011, konkrétně na 113 milionů Kč - z toho $85 \%$ jsou produkty se známkou FAIRTRADE ${ }^{\circledR}$ a $15 \%$ pak výrobky bez této známky. V roce 2013 se prodej fairtradových produktů opět zvýšil na 174 milionů Kč - z toho je $100 \%$ podíl produktů se známkou FAIRTRADE ${ }^{\circledR}$.

Tabulka 1: Vývoj prodeje fairtradových produktů v ČR v letech $2005-2012$ (v milionech Kс̌)

\begin{tabular}{|c|c|c|c|c|c|c|c|c|}
\hline $\mathbf{2 0 0 5}$ & $\mathbf{2 0 0 6}$ & $\mathbf{2 0 0 7}$ & $\mathbf{2 0 0 8}$ & $\mathbf{2 0 0 9}$ & $\mathbf{2 0 1 0}$ & $\mathbf{2 0 1 1}$ & $\mathbf{2 0 1 2}$ & $\mathbf{2 0 1 3}$ \\
\hline 3 & 10 & 27 & 41 & 50 & 80 & 92 & 113 & 174 \\
\hline
\end{tabular}

Zdroj: Fairtrade Česko a Slovensko, 2013. Fairtrade-cesko.cz: oficiální internetové stránky Fair trade Česká republika-výročni zpráva a infolist Fairtrade vroce 2013 [online]. [vid. 8. 6. 2014]. Dostupné z: http://www.fairtrade-cesko.cz/media/vyrocka_2011_web.1f2f.pdf a http://www.fairtrade-cesko.cz/media/ infolistobraty2013.c904.pdf

V druhé tabulce je popsána struktura prodávaných produktů fair trade v ČR. Největší podíl na prodávaném zboží se značkou fair trade má káva, kakao a čokoláda.

Tabulka 2: Struktura prodávaných produktů fair trade v ČR (v \%)

\begin{tabular}{|l|l|l|l|l|l|l|l|l|}
\hline Káva & $\begin{array}{l}\text { Kakao, } \\
\text { čokoláda, } \\
\text { cukrovinky }\end{array}$ & $\begin{array}{l}\text { Zpracované } \\
\text { potraviny }\end{array}$ & Kosmetika & $\begin{array}{l}\text { Další } \\
\text { nepotra- } \\
\text { vinové } \\
\text { zboží }\end{array}$ & Čaj & Nápoje & $\begin{array}{l}\text { Třtinový } \\
\text { cukr } \\
\text { a jiná } \\
\text { sladidla }\end{array}$ & Jiné \\
\hline $67 \%$ & $9 \%$ & $8 \%$ & $4 \%$ & $4 \%$ & $3 \%$ & $2 \%$ & $1 \%$ & $2 \%$ \\
\hline
\end{tabular}

Zdroj: Fairtrade Česká republika, 2013. Fairtrade-cesko.cz: oficiální internetové stránky Fair trade Česká republika - výroční zpráva [on-line]. [vid. 8. 6. 2014]. Dostupné z: http://www.fairtrade-cesko.cz/media/ vyrocka_2011_web.1f2f.pdf

\footnotetext{
17 Aktuální počet Fairtradových měst ve ČR je k dispozici na http://www.fairtradovamesta.cz/kde_jsou_ fer/mesta

${ }_{18}^{18}$ Aktuální počet Fairtradových škol v ČR je k dispozici na http://www.fairtradovamesta.cz/kde_jsou_fer/skoly

${ }^{19}$ Aktuální počet Fairtradových církví v ČR je k dispozici na ttp://www.fairtradovamesta.cz/kde_jsou_fer/cirkve
} 
V dalších dvou tabulkách lze vidět velký nárůst prodeje faitradových produktů ve světě celkem i ve většině vybraných států světa. Vysoká dynamika růstu prodeje fairtradových produktů v ČR je jistě pozitivní vývoj, ale úrovně srovnatelně velkých států (např. Švýcarsko, Rakousko atd.) v ČR stále nedosahujeme.

Tabulka 3: Vývoj prodeje fairtradových produkti̊ ve světě v letech 2005 - 2012 (v miliardách Eur)

\begin{tabular}{|c|c|c|c|c|c|c|c|}
\hline $\mathbf{2 0 0 5}$ & $\mathbf{2 0 0 6}$ & $\mathbf{2 0 0 7}$ & $\mathbf{2 0 0 8}$ & $\mathbf{2 0 0 9}$ & $\mathbf{2 0 1 0}$ & $\mathbf{2 0 1 1}$ & $\mathbf{2 0 1 2}$ \\
\hline 1,1 & 1,6 & 2,4 & 3,0 & 3,4 & 4,3 & 4,9 & $4,8^{*}$ \\
\hline
\end{tabular}

*V roce 2012 je nižši obrat prodeje fairtradových produktů ve světě způsoben nezapočitáním objemu prodeje fairtradových výrobků z USA, protože Fair Trade USA již není členem Fairtrade International, po svém odstoupeni ke dni 31. 12. 2011.

Zdroj: Fairtrade international, 2014. Fairtrade.net: oficiální internetové stránky Fairtrade international výročni zprávy 2005 až 2012 [on-line]. [vid. 26. 7. 2014]. Dostupné z: http://www.fairtrade.net/annualreports.html

Tabulka 4: Vývoj prodeje fairtradových produktů ve vybraných zemích světa v letech 2005 2012 (v milionech Eur)

\begin{tabular}{|l|c|c|c|c|c|c|c|c|}
\hline & $\mathbf{2 0 0 5}$ & $\mathbf{2 0 0 6}$ & $\mathbf{2 0 0 7}$ & $\mathbf{2 0 0 8}$ & $\mathbf{2 0 0 9}$ & $\mathbf{2 0 1 0}$ & $\mathbf{2 0 1 1}$ & $\mathbf{2 0 1 2}$ \\
\hline Francie & 109,1 & 166,0 & 210,0 & 255,6 & 287,7 & 303,3 & 315,4 & 345,8 \\
\hline Německo & 70,9 & 110,0 & 141,7 & 212,8 & 267,5 & 340,0 & 400,5 & 533,1 \\
\hline Kanada & 34,8 & 53,8 & 79,6 & 123,8 & 202,0 & 194,9 & 199,8 & 197,3 \\
\hline Švýcarsko & 133,8 & 142,3 & 158,1 & 168,8 & 180,2 & 219,9 & 264,8 & 311,6 \\
\hline Finsko & 13 & 22,5 & 34,6 & 54,4 & 86,9 & 93,0 & 102,7 & 152,3 \\
\hline Nizozemí & 36,5 & 41,0 & 47,5 & 60,9 & 85,8 & 119,0 & 147,3 & 186,1 \\
\hline Rakousko & 25,6 & 41,7 & 52,8 & 65,2 & 72,0 & 87,0 & 100,0 & 107,0 \\
\hline Japonsko & 3,4 & 4,1 & 6,2 & 9,6 & 11,3 & 14,4 & 59,3 & 71,4 \\
\hline
\end{tabular}

Zdroj: Fairtrade international, 2014. Fairtrade.net: oficiální internetové stránky Fairtrade international- výroční zprávy 2005 až 2012 [on-line]. [vid. 26. 7. 2014]. Dostupné z: http://www.fairtrade.net/annual-reports.html

\section{Fair trade a zadávání veřejných zakázek}

Mohlo by se zdát, že zohledňování fairtradových kritérií při zadávání veřejných zakázek by neměl být problém. Ovšem povaha veřejné zakázky si vynucuje pozornost $\mathrm{z}$ hlediska právní regulace a ekonomických aspektů. Pokud tedy chce zadavatel veřejné zakázky zohlednit fairtradová kritéria, musí se podle Horáčka $(2012$, s. 13, 14) opírat o tři základní pilíre:

1. Znalost principů fair trade a možností certifikace v rámci systému fair trade tak, aby mohly být zohledněny všechny př́nosy, které použití této standardizace a certifikace daného produktu pro zadavatele - z hlediska lokálních zájmů i z hlediska globálních cílů - přináší.

2. Politickou podporu udržitelného zadávání veřejných zakázek a v širším slova smyslu o politickou podporu udržitelného rozvoje a cílů udržitelného rozvoje.

3. Správný procesní postup při zadávání veřejné zakázky tak, aby proces zadání, jeho hodnocení a následný výsledek byl zcela v souladu jak s evropskou, tak i národní legislativou.

\subsection{Společenská odpovědnost a zadávání veřejných zakázek}

Společenská odpovědnost je v prŕípadě veřejné správy definována jako souhrn všech činností, postupů a výsledků, které orgány veřejné správy realizují pro uskutečnění své vize a jdou nad rámec poslání a povinností, uvedených $\mathrm{v}$ zákonech ${ }^{20}$.

\footnotetext{
${ }^{20}$ Více informací na http://www.spolecenskaodpovednostfirem.cz/news/vite-ze-i-urad-muze-byt-spolecenskyodpovedny-/
} 
Jedním z velmi účinných nástrojů realizace společensky odpovědné veřejné správy je také společensky odpovědné zadávání veřejných zakázek.

Veřejná zakázka je v §8 Zákona č. 137/2006 Sb., o veřejných zakázkách, ve znění pozdějších předpisů (dále jen ZVZ) definována jako zakázka realizovaná na základě smlouvy mezi zadavatelem a jedním či více dodavateli, jejímž předmětem je úplatné poskytnutí dodávek či služeb nebo úplatné provedení stavebních prací.

Podle Jurčíka (2011, s. 11) je klíčové pro posouzení, zda něco je, nebo není veřejnou zakázkou pojem zadavatel. Pokud je subjekt označen jako zadavatel, musí se při nakupování statků řídit zákonem o veřejných zakázkách. ZVZ uvádí tři typy zadavatelů - veřejní zadavatelé, dotovaní zadavatelé a sektoroví zadavatelé.

Z hlediska společenské odpovědnosti je podstatný $\S 44$ ZVZ, odstavec 10, který uvádí, že zadavatel může $\mathrm{v}$ zadávacích podmínkách uvést též požadavky týkající se zvláštních podmínek na plnění veřejné zakázky, a to zejména v sociální oblasti, v oblasti zaměstnanosti nebo v oblasti životního prostředí.

Účelem společensky odpovědného zadávání veřejných zakázek je napomáhat oblastem, které v dnešní společnosti strádají - podle Jurčíka (2011) se jedná se především o ekologické zadávání a udržitelný rozvoj, sociální aspekty (podpora zaměstnanosti a znevýhodněných osob, dodržování standardů pracovního prostředí atd.) a podporu malých podnikatelů. Všechny tyto oblasti, se dají podpořit také zahrnutím principů fair trade do zadávání veřejných zakázek orgány veřejné správy.

Společensky odpovědné zadávání veřejných zakázek orgány veřejné správy, může využít ekonomických zájmů firem, které chtějí získat veřejnou zakázku k prosazování ekologických, sociálních a jiných cílů (napřr. zapojení malých podniků a živnostníků do veřejných soutěží atd.). Neméně důležitý je společensky (eticky) prospěšný vliv takového zadávání veřejných zakázek - jedná se o př́klad pro obdobné jednání občanů a firem ${ }^{21}$.

Podle Jurčíka (2011) společensky odpovědné zadávání veřejných zakázek přispívá k tomu, aby veřejné prostředky byly vynakládány hospodárně, účelně a efektivně (tzv. princip 3E).

Tyto pojmy jsou definovány v Zákoně č. 320/2001 Sb., o finanční kontrole:

hospodárností se rozumí takové použití veřejných prostředků k zajištění stanovených úkolů, kterým je těchto prostředků použito co nejméně, a to při dodržení odpovídající kvality plněných úkolů,

efektivností se rozumí takové použití veřejných prostředků, kterým se dosáhne nejvýše možného rozsahu, kvality a prínosu plněných úkolů ve srovnání s objemem prostředků vynaložených na jejich plnění,

účelností se rozumí takové použití veřejných prostředků, které zajistí optimální míru dosažení cílů při plnění stanovených úkolů.

$\mathrm{V}$ roce 1992 byl na Summitu Organizace spojených národů (OSN) o udržitelném rozvoji v brazilském Rio de Janeiru přijat strategický dokument Agenda 21, která stanovuje konkrétní kroky k prosazování udržitelného rozvoje jako základ budoucího života na naší planetě. Tento Summit Země stanovil udržitelný rozvoj základem vývoje, integrující třri pilíre udržitelného rozvoje - hospodářský růst, sociální rozvoj a ochranu životního prostředí - jako vzájemně závislé a vzájemně se podporující prvky dlouhodobého rozvoje.

Společenská odpovědnost firem je také velmi důležitá při podpoře principů fair trade. Jedná se o dobrovolné začlenění sociálních, ekonomických a ekologických hledisek do každodenních firemních operací a vztahů s firemními stakeholders (všechny osoby a instituce, které mají s podnikem cokoli do činění). Organizace NaZemi ve své studii „Společenská odpovědnost outdoorových firem“ kde bylo zkoumáno 47 outdoorových firem v letech 2010 až 2012 ohledně jejich společenské odpovědnosti. Bylo zjištěno, že plat vietnamského dělníka $\mathrm{v}$ továrně na outdoorové oblečení je kolem 4 Kč na hodinu, přitom

\footnotetext{
${ }^{21}$ Více informací http://www.mvcr.cz/clanek/verejne-zakazky-a-jejich-spolecensky-odpovedne-zadavani.aspx
} 
maloobchodní obrat evropského trhu s outdoorovým zbožím je 10 miliard eur ročně. Proto je velmi důležité, aby se i firmy chovali společensky odpovědně i s pomocí iniciativ navazujících na fair trade, jako jsou výše uvedené FWF, WGDN, FSC, nebo FLP.

\subsection{Zapojení fair trade do zadávání veřejných zakázek}

Evropská unie a její členské státy už od devadesátých let podporují společensky odpovědné zadávání veřejných zakázek prostřednictvím fair trade a jeho principů, např́íklad prostřednictvím Usnesení Evropského parlamentu o novém vývoji voblasti veřejných zakázek 18. 5. 2010; 2009/2175 nebo Usnesení o spravedlivém obchodu a rozvoji.

Jako klíčový, pro právní jistotu při uplatňování fair trade principů v zadávání veřejných zakázek v celé Evropské unii, se stal rozsudek Evropského soudního dvora z 10. 5. 2012 číslo C-368/10. V tomto rozsudku se jedná o právní spor mezi nizozemskou vládou a Evropskou komisí. Nizozemská Provincie North Holland vypsala veřejnou zakázku na zajištění dodávky nápojových automatů s certifikační známkou Max Havelaar a „EKO“22.

$\mathrm{Na}$ to reagovala Evropská komise žalobou k Evropskému soudnímu dvoru na uvedenou provincii za údajné nedodržování pravidel EU při veřejném zadávání. Evropský soudní dvưr jasně uvedl, že veřejní zadavatelé můžou volit kritéria environmentální i sociální povahy do vypisovaných veřejných zakázek. Výslovně soud také uvedl, že veřejný zadavatel může v kritériích (technické specifikaci) uvést požadavek na produkt fairtradového původu, a to za předpokladu, že lze požadovaná minimální kritéria doložit i jiným způsobem (princip nediskriminace), než předem stanovenými certifikacemi.

Politická podpora principů spravedlivého obchodu v ČR je obsažena mimo výše uvedeného ZVZ ve Strategickém rámci udržitelného rozvoje České republiky, schváleného vládou ČR v lednu 2010, kde vláda vyslovila jednoznačnou podporu principům trvale udržitelného rozvoje ve formě tří základních cílů rozvoje moderní společnosti - ekonomický, environmentální a sociální rozvoj. Dále je v Strategickém rámci uvedeno „Veřejná správa bude využívat svou kupní sílu k nákupu služeb a zboží tak, aby naplňovala zároveň sociální a environmentální cíle, čímž bude přispívat k posílení sociální soudržnosti a udržitelného rozvoje."

Také ve svém programovém prohlášení z února 2014 se vláda ČR zavazuje: „Vláda připraví nový zákon o veřejných zakázkách, který bude reflektovat moderní trendy zadávání v Evropské unii a který sladí požadavky na důslednou transparentnost zadávacích řízení s cílem zamezit korupci a zajistit výběr optimálního dodavatele.“

Fair trade nelze (vzhledem k omezené struktuře fair trade výrobků) zapojit do všech typů veřejných zakázek. Jedná se především o veřejné zakázky menšího rozsahu na dodávky a služby, jako jsou stravovací služby (dodávka čaje pro úřad), občerstvení na společenské akce, dárkové předměty, oblečení, nábytek atd.

Jurčík (2011) uvádí, že fair trade požadavky lze zapojit do zadávacího procesu dvěma způsoby, a to na začátku, nebo na konci procesu zadávání veřejných zakázek:

První možností (na počátku procesu zadávání veřejných zakázek - fáze vymezování technické specifikace) je využití technické specifikace veřejné zakázky - jedná se o jasně vymezené požadavky na fair trade (např. ovoce na catering pouze při splnění uvedených fair trade principů) už $\mathrm{v}$ zadávací dokumentaci. $\mathrm{V}$ tomto př́padě si zadavatel může udělat

\footnotetext{
${ }^{22}$ Max Havelaar je označení kvality: Fair trade pro malé zemědělce - nezávislá organizace zaručuje, že produkty nebo suroviny byly zakoupeny na základě principů Fairtrade od družstev drobných zemědělců a pracovníků na plantážích v rozvojových zemích.

Označení kvality EKO - představuje používání ekologických metod produkce v zemi původu. To zaručuje, že například káva byla pěstována za použití šetrných k životnímu prostředí, které chrání biologickou rozmanitost a místní ekosystém. Nejsou použity žádné chemické hnojiva ani chemické syntetické pesticidy.
} 
průzkum, kolik dodavatelů, je schopno takový požadavek v technické specifikaci zadané zakázky splnit. Důvod je zřejmý, pokud by se do tendru přihlásil pouze jeden uchazeč, musí být tento zrušen. Tato varianta zapojení principů fair trade do veřejných zakázek se jeví jako vhodná. Už v zadání veřejné zakázky jsou jasně a srozumitelně vymezené a vyjmenované minimální požadavky na dodávané zboží či služby.

Př́íklad využití technické specifikace pro zapojení principů fair trade do veřejných zakázek - nákup volejbalových míčů:

Předmět veřejné zakázky: nákup volejbalových míčů

Účel veřejné zakázky: uzavření kupní smlouvy s jedním dodavatelem

Název a sídlo zadavatele: Základní škola, Brno, Xxxxxxxxxx, př́íspěvková organizace

Xxxxxxxxxxxx, Brno-Xxxxxxx, $\mathrm{xxx} \mathrm{xx}$

IČ zadavatele: $\mathrm{xxxxxxxx}$

Typ veřejné zakázky: veřejná zakázka malého rozsahu na dodávky

Předmět veřejné zakázky: Předmětem veřejné zakázky je dodávka nových volejbalových míčů pro Základní školu Xxxxxxxxxxx.

Kontaktni osoba zadavatele - telefon, e-mail: $\mathrm{Xxxxxxx} \mathrm{Xxxxxxxxx,+420xxxxxxxxx,}$ xxxxxx.xxxxx@xxxxx.cz

Místo plněni: Brno

Kód CPV: 37452900-0

Předpokládaná cena bez DPH: 30 000,- Kč

Předpokládané množství plnění: 30 kusů

Datum zahájení plnění: 1.1.2013, ukončení plnění: 31.3.2013

Datum trvání veřejné zakázky: 3 měsíce

Druh řizení: poptávkové řízení s oslovením 5 dodavatelů a následným zveřejněním výzvy na internetu

Datum doručení nabidky: 10.11 .2012

Datum zverejnění: 20.9.2012

Hodnotíci kritéria: Hodnocení nabídek základní hodnotící kritérium - nejnižší nabídková cena bez DPH.

Technické specifikace: Všechny volejbalové míče musí být vyrobeny v souladu s Usnesením Evropského parlamentu o spravedlivém obchodu a rozvoji (2005/2245(INI)), kde jsou podmínky pro fair trade blíže specifikovány.

Druhou možností (na konci procesu zadávání veřejných zakázek - fáze hodnocení) je využití hodnocení ekonomické výhodnosti nabídky, kdy v rámci hodnotících kritérií bude uvedeno dilč́ kritérium - fair trade.

$\mathrm{K}$ hodnocení veřejných zakázek se přistupuje v podstatě dvěma způsoby, jedním je nejnižší nabídková cena a druhým je ekonomická výhodnost nabídky. Hodnocení pomocí nejnižší nabídkové ceny - tady se dají principy fair trade použít pouze $\mathrm{v}$ technické specifikaci veřejné zakázky - viz. př́klad využití technické specifikace. U hodnocení pomocí ekonomické výhodnosti nabídky se fair trade principy dají použít jako jedno z kritérií hodnocení. Problematické může být správné nastavení vah jednotlivých dílčích kritérií. Kritérium nejnižší nabídkové ceny tak zde neplatí. Tato varianta hodnocení je prospěšná, protože jsou upřednostněny produkty s lepšími vlastnostmi. 


\section{Příklad využití hodnocení ekonomické výhodnosti nabídky, kdy v rámci hodnotících kritérii bude uvedeno dílčí kritérium - fair trade:}

Předmět veřejné zakázky: nákup hořké čokolády

Účel veřejné zakázky: uzavření kupní smlouvy s jedním dodavatelem

Název a sídlo zadavatele: Statutární město Brno

IC zadavatele: $\mathrm{xxxxxxxx}$

Typ veřejné zakázky: veřejná zakázka malého rozsahu na dodávky

Předmět veřejné zakázky: Předmětem veřejné zakázky je dodávka hořké čokolády pro Statutární město Brno.

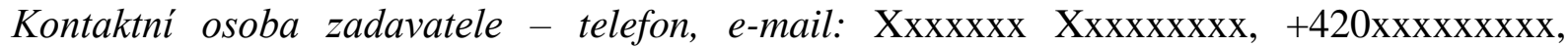
xxxxxx.xxxxx@xxxxx.cz

Místo plnění: Brno

Kód CPV: 15842100-3

Předpokládaná cena bez DPH: 10 000,- Kč

Předpokládané množství plněni: 100 kusů

Datum zahájení plnění: 1.3.2013, ukončení plněni: 30.4.2013

Datum trváni veřejné zakázky: 2 měsíce

Druh řizení: poptávkové řízení s oslovením 5 dodavatelů a následným zveřejněním výzvy na internetu

Datum doručení nabídky: 10.12.2012

Datum zveřejnění: 20.11.2012

Specifikace veřejné zakázky:

Jedná se o veřejnou zakázku malého rozsahu na dodávku 100 kusů hořké čokolády v určeném termínu v roce 2013 jako dárkový předmět. Hořkou čokoládu je možné dodat v běžné kvalitě, ve fair trade kvalitě a také s obsahem minimálně $80 \%$ kakaové sušiny.

Pokud se jedná o kvalitu fair trade, je dodavatel povinen prokázat, že hořká čokoláda byla vyrobena v souladu s Usnesením Evropského parlamentu o spravedlivém obchodu a rozvoji (2005/2245(INI)). Tyto podmínky jsou bez dalšího splněny, jestliže nabízené výrobky mají značku FAIRTRADE ${ }^{\circledR}$ dle certifikace FLO, nebo jsou dovážené prostřednictvím fair trade organizací (členové WFTO). Dodavatelé mohou prokázat shodu s požadavky také jiným vhodným způsobem.

V př́padě obsahu kakaové sušiny je dodavatel povinen stvrdit a deklarovat před podepsáním kupní smlouvy obsah této kakaové sušiny v čestném prohlášení. Přičemž důsledky porušení a sankce jsou předmětem kupní smlouvy.

Dodavatel může současně splnit požadavky na fair trade kvalitu i na obsah kakaové sušiny.

Hodnocení nabídek:

Zadavatel se rozhodl pro kritérium - ekonomická výhodnost nabídky. Nabídky budou posuzovány podle uvedených kritérií se stanovenými váhami:

- nabídková cena - 50\%

- fair trade produkt - 30\%

- obsah kakaové sušiny minimálně $80 \%$ - $20 \%$

Podle Ochrany (2011) lze ke stanovení vah jednotlivých dílčích kritérií využít také tyto tři metody - Metodu alokace 100 bodů ze strany zadavatele k procentnímu určení vah dílčích kritérií, Metodu párového srovnávání a Metodu postupného rozvrhu váhy. ${ }^{23}$ Rozhodnutí je na samotném zadavateli.

Obě varianty lze v praxi využít, ovšem jako vhodnější se jeví využití technické specifikace pro zapojení principů fair trade. Jednak je to právně podpořené rozsudkem Evropského

\footnotetext{
${ }^{23}$ Více informací o jednotlivých metodách viz. Ochrana (2011)
} 
soudního dvora a také se jedná o jasné a srozumitelné vymezení požadavků pro možné dodavatele. U druhé varianty, tedy využití hodnocení ekonomické výhodnosti nabídky, kdy v rámci hodnotících kritérií bude uvedeno dílčí kritérium - fair trade může být sporné správné nastavení vah pro jednotlivá kritéria a také není možné rozhodnout podle nejnižší nabídkové ceny - možný spor o ekonomickou výhodnost nabídky.

\subsection{Průzkum u vybraných certifikovaných subjektů}

Všechna výše uvedená Fairtradová města v ČR, tedy ta, která již status Faritradové město získala (k 1. 7. 2014 je jich sedm), byla v rámci analýzy aplikace fair trade kritérií ve veřejných zakázkách oslovena dne 15. 6.2014 s těmito dotazy:

1. V jaké oblasti (jaký typ) veřejných zakázek uplatňujete fairtradová kritéria?

2. Jakým způsobem je aplikujete do zadávání veřejných zakázek? (např. v technické specifikaci veřejné zakázky, nebo u ekonomické výhodnosti nabídky v rámci hodnotících kritérií?)

Ze sedmi oslovených Fairtradových měst, odpověděla k 5. 7. 2014 čtyři. V Českém Krumlově a Vsetíně neaplikují fair trade kritéria do veřejných zakázek. V Litoměřicích spolu s dalšími evropskými partnery mají podaný projekt u Evropské komise a v př́padě, že vyjde, plánují v jeho rámci vypracování hloubkové analýzy veškerých nákupů města včetně sestavení plánu a směrnic, jak odpovědně nakupovat. Třebíč aplikovala fair trade principy např́iklad do veřejné zakázky malého rozsahu na dodávky fair trade kávy, čaje, cukru, sušenek a čokolády. ${ }^{24}$ Předpokládaná hodnota zakázky byla 40000 , - Kč bez DPH a fair trade kritéria byla aplikována $\mathrm{v}$ technické specifikaci této veřejné zakázky.

Stejně tak, jako Fairtradová města bylo v rámci analýzy aplikace fair trade kritérií ve veřejných zakázkách osloveno dne 15. 62014 všech osm Fairtradových škol se stejnými výše uvedenými dotazy. Z osmi škol odpověděly ke dni 5. 7. 2014 dvě. Ekonomická fakulta Jihočeské univerzity v Českých Budějovicích a Základní škola Svážná v Mostě, obě tyto školy neaplikují fair trade kritéria ve veřejných zakázkách.

Z průzkumu je patrné, že aplikace fairtradových kritérií do veřejných zakázek není mezi zadavateli př́lišs rozšířená. V jednom případě byla využita první výše popsaná možnost aplikace fairtradových kritérií v technické specifikaci veřejné zakázky.

\section{Závěr}

Veřejné zakázky jako takové, jsou ve společnosti bohužel většinou vnímány především díky korupci a z toho vzniklých skandálů. Tento př́spěvek se na veřejné zakázky dívá tak, že je lze využít jako jeden z nástrojů ke zlepšení života společnosti. Prostřednictvím aplikování sociálních, environmentálních i ekonomických aspektů (konkrétně např. prostřrednictvím principů fair trade) do zadávaných veřejných zakázek.

Př́spěvek měl za cíl analyzovat a popsat možnosti, jak aplikovat společenskou odpovědnost prostřednictvím fair trade principů do veřejných zakázek. Na základě realizovaného zkoumání lze říci, že při dodržení správného postupu mohou zadavatelé aplikovat fair trade principy do zadávání veřejných zakázek. Jedná se především o veřejné zakázky menšího rozsahu. Do budoucna lze uvažovat i o některých podlimitních veřejných zakázkách. Záleží tedy především na vůli príslušných zadavatelů, zda chtějí principy fair trade aplikovat do zadávaných veřejných zakázek. Z provedeného průzkumu ovšem vyplývá, že vůle zadavatelů v ČR k aplikaci fairtradových kritérií do zadávání veřejných zakázek v praxi zatím není př́liš velká.

Jsem přesvědčena, že odpovědné nákupy mají budoucnost. Životní a pracovní podmínky lidí $\mathrm{v}$ rozvojových zemích je možné do značné míry ovlivnit spotřebním chováním a také prostřednictvím společensky odpovědného zadávání veřejných zakázek.

\footnotetext{
${ }^{24}$ Celá zakázka je dostupná na https://zakazky.trebic.cz/contract_display_180.html
} 


\section{Literatura}

[1] Asociace společenské odpovědnosti. Spolecenska odpovednost firem.cz: oficiálni internetová stránka Asociace společenské odpovédnosti, o.p.s. [online]. [vid. 10. června 2014]. Dostupné z: http://www.spolecenskaodpovednostfirem.cz/news/vite-ze-i-uradmuze-byt-spolecensky-odpovedny-/

[2] Centrum environmentálnej a etickej výchovy Živica. Zivica.sk: oficiální internetová stránka neziskové organizace Centrum environmentálnej a etickej výchovy Živica [online]. [vid. 20. července 2014]. Dostupné z: http://www.zivica.sk/

[3] Ekumenická akademie Praha. Ekumland.cz: oficiální internetová stránka Ekumenické akademie Praha [online]. [vid. 25. června 2014]. Dostupné z: http://www.ekumakad.cz/

[4] European Fair Trade Association. European-fair-trade-association.org: oficiální internetová stránka European Fair Trade Association [online]. [vid 20. června 2014]. Dostupné z: http://www.european-fair-trade-association.org/efta/

[5] Fair Wear Foundation. Fairwear.org: oficiální internetové stránky Fair Wear Foundation [online]. [vid. 19. června 2014]. Dostupné z: http://www.fairwear.org/

[6] Fairtrade Česko a Slovensko. Fairtrade-cesko.cz: oficiální internetová stránka Fairtrade Česko a Slovensko [on-line]. [vid. 20. června 2014]. Dostupné z: http://www.fairtradecesko.czl

[7] Fairtrade Česko a Slovensko. Fairtrade-cesko.cz: oficiální internetová stránka Fairtrade Česko a Slovensko - historie [on-line]. [vid. 26. července 2014]. Dostupné z: http://www.fairtrade-cesko.cz/\#!o-nas/nasehistorie

[8] Fairtrade Česko a Slovensko 2013. Fairtrade-cesko.cz: oficiální internetové stránky Fair trade Česká republika - infolist Fairtrade v roce 2013 [on-line]. [vid. 8. června 2014]. Dostupné z: http://www.fairtrade-cesko.cz/media/infolistobraty2013.c904.pdf

[9] Fairtrade Česko a Slovensko 2013. Fairtrade-cesko.cz: oficiální internetová stránka Fair trade Česko a Slovensko - výroční zpráva [on-line]. [vid. 8. června 2014]. Dostupné z: http://www.fairtrade-cesko.cz/media/vyrocka_2011_web.1f2f.pdf

[10] Fairtrade international. Fairtrade.net: oficiální internetová stránka Fairtrade international [on-line]. [vid. 23. června 2014]. Dostupné z: http://www.fairtrade.net/

[11] Fairtrade international. Fairtrade.net: oficiální internetové stránky Fairtrade international - výroční zprávy 2005 až 2013 [on-line]. [vid. 13. srpna 2014]. Dostupné z: http://www.fairtrade.net/annual-reports.html

[12] Fairtrade Towns. Fairtradetowns.org: oficiální internetová stránka Fairtrade Towns [online]. [vid. 1. července 2014]. Dostupné z: htttp://www.fairtradetowns.org

[13] Fairtradová města. Fairtradovamesta.cz: oficiální internetová stránay Fairtradová města [online]. [vid. 18. června 2014]. Dostupné z: http://www.fairtradovamesta.cz/

[14] Flower Label Program. Fairflowers.de: oficiální internetová stránka Fair Label Program [online]. [vid. 19. června 2014]. Dostupné z: http:// www.fairflowers.de

[15] FLO-CERT. Flo-cert.net: oficiálni internetová stránka FLO-CERT [online]. [vid 27. června 2014]. Dostupné z: http://www.flo-cert.net/

[16] Forest Stewardship Council. Czechfsc.cz: oficiálni internetová stránka Forest Stewardship Council [online]. [vid 25. června 2014]. Dostupné z: http://www.czechfsc.cz 
[17] HORÁČEK, T., 2012. Fairtradové veřejné zakázky [online]. [vid 3. července 2014] ISBN 978-80-905146-6-9. Dostupné z: http://www.nazemi.cz/sites/default/files/ fairtradove-verejne-zakazky-web.pdf

[18] JURČÍIK, J., 2011. Vztah veřejných zakázek a fair trade. Brno: NaZemi - společnost pro fair trade [online]. [vid 17. června 2014]. ISBN 978-80-254-9102-7. Dostupné z: http://www.nazemi.cz/sites/default/files/analyza_web.pdf

[19] Mamacoffe, s.r.o. Mamacoffe.cz: oficiální internetová stránka Mamacoffe, s.r.o. [online]. [vid 27. června 2014]. Dostupné z: http://www.mamacoffee.cz/

[20] Miko Káva, s.r.o. Mikokava.cz: oficiální internetová stránka Miko Káva, s.r.o. [online]. [vid 26. července 2014]. Dostupné z: http://www.mikocoffee.com/uvod.html

[21] Ministerstvo životního prostředí. Mzp.cz: oficiální internetová stránka Ministerstva životniho prostředi - Strategický rámec udržitelného rozvoje $\check{C} R$ [online]. [vid 17. června 2014]. Dostupné z: http://www.mzp.cz/C1257458002F0DC7/cz/strategie_ udrzitelneho_rozvoje/\$FILE/KM-SRUR_CZ-20100602.pdf

[22] Ministerstvo životního prostředí. Mzp.cz: oficiální internetová stránka Ministerstva životniho prostředi - Agenda 21 [online]. [vid 29. června 2014]. Dostupné z: http://www.mzp.cz/cz/mistni_agenda_21

[23] MRAVCOVÁ, J. a J. ŠŤASTNÁ, 2014. Veřejné zakázky a jejich společensky odpovédné zadávání [online]. [vid. 16. června 2014]. Dostupné z: http://www.mvcr.cz/ clanek/verejne-zakazky-a-jejich-spolecensky-odpovedne-zadavani.aspx

[24] Nadácia Integra. Integra.sk: oficiální internetová stránka Nadácie Integra [online]. [vid 26. července 2014]. Dostupné z: http://www.integra.sk/sk/

[25] NaZemi. Nazemi.cz: oficiální internetová stránka NaZemi [online]. [vid 30. června 2014]. Dostupné z: http://www.nazemi.cz/

[26] NaZemi. Nazemi.cz: oficiální internetová stránka NaZemi - studie Společenská odpovědnost outdoorových firem [online]. [vid 30. června 2014]. Dostupné z: http://www.nazemi.cz/sites/default/files/spolecenska_odpovednost_outdoorovych_firem_ shrnuti.pdf

[27] OCHRANA, F., 2011. Veřejné výdajové programy, veřejné projekty a zakázky (jejich tvorba, hodnoceni a kontrola.). Brno: Wolters Kluwer ČR. ISBN 978-80-7357-644-8.

[28] Soudní dvůr Evropské unie. Curia.europa.eu: oficiální internetová stránka Soudního dvora Evropské unie [online]. [vid. 2. května 2014]. Dostupné z: http://curia.europa.eu/juris/document/document.jsf;jsessionid=9ea7d2dc30db387e4c49c1 f2409c98eaed50e8a15e4d.e34KaxiLc3qMb40Rch0SaxuKbNb0?text=\&docid=123932\& pageIndex $=0 \&$ doclang $=C S \&$ mode $=$ req $\&$ dir $=\& o c c=$ first $\&$ part $=1 \&$ cid $=9301$

[29] Třebíč. Trebic.cz: oficiální internetová stránka města Třebíče - Veřejná zakázka: Ev. č. 14120001 Nákup fairtradových produktů [online]. [vid 28. června 2014]. Dostupné z: https://zakazky.trebic.cz/contract_display_180.html

[30] Vláda ČR. Vlada.cz: oficiální internetová stránka vlády $\check{C} R$ - Programové prohlášení vlády [online]. [vid 3. července 2014]. Dostupné z: http://www.vlada.cz/assets/mediacentrum/dulezite-dokumenty/programove_prohlaseni_unor_2014.pdf

[31] Werkgroep Duurzame Natuursteen. Duurzaamnatuursteen.nl: oficiální internetová stránka Werkgroep Duurzame Natuursteen [online]. [vid 28. června 2014]. Dostupné z: http://duurzaamnatuursteen.nl/en/page/home_en 
[32] World Fair Trade Organization. Wfto.com: oficiální internetová stránka World Fair Trade Organization [online]. [vid 16. června 2014]. Dostupné z: http://www.nazemi.cz/

[33] Zákon č. 137/2006 Sb., o veřejných zakázkách, ve znění pozdějších předpisů.

[34] Zákon č. 320/2001 Sb., o finanční kontrole, ve znění pozdějších předpisů. 